\title{
MARKETING RESEARCH FOR CHOOSING THE PROMOTIONAL MESSAGE CONTENT FOR DOMESTIC ORGANIC PRODUCTS
}

\author{
Suzana Salai ${ }^{1}$, Tomislav Sudarević2 ${ }^{2}$ Nenad Đokic ${ }^{3}$, Ljubomir Pupovac $^{4}$
}

\begin{abstract}
Summary
Choosing the content of promotional messages is a part of the activities of integrated marketing communication. As far as organic products in the world are concerned, research related to the choice of promotional message content is the object of much attention, primarily based on the conduct of research among the consumers of these product (information for defining the aim of promotion, creating and testing promotional messages, selecting media and media mix, and determining the number and frequency of promotional events). Promoting domestic organic products also inevitably implies conducting consumer-centred marketing research, in order to choose the appropriate promotional message. In this respect, this article defines several goals: study the choice of the promotional message content in relation to other activities of integrated marketing communication; consider this question in the context of relevant foreign market research into organic product consumers; determine the level of marketing research, which could be used for approaching the issue from the domestic perspective; and establish which recommendations and implication could be generated when domestic organic products are concerned.
\end{abstract}

Key words: Organic products, consumer-centred marketing research, integrated marketing communication, integrated marketing communication activities, choosing promotional message content.

JEL: M31, M37

1 Ph.D., Full Professor in retirement, Faculty of Economics Subotica, University of Novi Sad, Segedinski put 9-11, 24000 Subotica, Serbia, E-mail: sazu@ef.uns.ac.rs

2 Ph.D., Associate Professor, Faculty of Economics Subotica, University of Novi Sad, Segedinski put 9-11, 24000 Subotica, Serbia, E-mail: tsudarevic@yahoo.com

3 M.A., Assistant, Faculty of Economics Subotica, University of Novi Sad, Segedinski put 9-11, 24000 Subotica, Serbia, E-mail: djokicn@ef.uns.ac.rs

4 M.Sc., Assistant, Faculty of Economics Subotica, University of Novi Sad, Segedinski put 9-11, 24000 Subotica, Serbia, E-mail: ljubomirp@ef.uns.ac.rs

EP 2014 (61) 2 (501-515) 


\section{Introduction}

Two approaches are identifiable regarding the placement of homemade organic products. The first approach (e.g. März et al., 2012) primarily recommends exporting domestic organic products (especially to certain EU countries: Italy, France, Great Britain and Germany), with the rationale that foreign markets could absorb the surplus supply of organic products, which is not certain on the domestic market, among other things, due to the population's insufficient purchasing power and a long time period required to change eating habits. The other approach (e.g. Sudarević et al., 2011) primarily highlights the need to develop the domestic market, i.e. increase the consumption of organic products by domestic consumers, with lower risks compared to export orientation as the main advantage. The argument in favour of this approach is the case of Hungary, where organic products were predominantly placed on foreign markets, but problems occurred when lower-priced organic products of the same quality level from India, China, Egypt and other countries entered their export markets.

Regardless of whether the placement of domestic organic products will be oriented to export or the domestic market, it is essential for all participants in the value chain to have organic product accepted by the final consumers. This implies the need to adopt a marketing concept, i.e. achieve the company's objectives by means of higher efficiency than its competitors in creating, delivering and communicating greater consumer value on the chosen target markets (Kotler, Keller, 2006), that is, achieving corporate objectives through meeting customers' needs better than their competitors (Jobber, Fahy, 2006) - in a nutshell, marketability and profitability. Marketing concept is recognised as vital for food industry in general (Grunert et al., 1996), and consumers and their satisfaction are identified as the key factor of future organic product market as well (Hughner et al., 2007).

Promotion, which is the research subject in the broader sense in this article, is not only a marketing mix instrument, but also one of the marketing functions in the company, i.e. a marketing activity performed within the company, referring to planning and organising the company's promotional strategy and tactics (Salai, Grubor, 2011). Actually, together with marketing research, product planning and development, and distribution, promotion features as a marketing function where, based on marketing research information, the promotional message is created for the product or service that is to be available to consumers by means of chosen marketing channels at the appropriate price. Another point that must be mentioned in relation to promotion is that the period since the 1990 s is dominated by the trend of integrated marketing communication (Salai, Grubor, 2011), which includes marketing communication integrated at three levels: integrating marketing instruments into the marketing mix; integrating promotion instruments into the promotion mix; and integration at the level of a unique message to actual and potential consumers, i.e. the market. The need for integrated marketing communications in food industry is stated in article written by Mesaroš at al. (2013).

As far as domestic organic products are concerned, promotional activities have so far been researched in relation to the application of the integrated marketing communication in promoting these products (Salai, 2004), or promoting the brands of these products (Salai, 
2005). However, bearing in mind that promotion requires previous integrated marketing communication activities, the research subject in this study is conducting consumer-centred marketing research with the aim of choosing the content of the promotional message for domestic organic products. Together with defining the structure, form and source of the promotional message, choosing its content qualifies as creating the promotional message within the integrated marketing communication activities (Salai, Grubor, 2011). The choice of the content of the promotional message is extremely important, and is dynamically changed under the influence of changes in consumers' attitudes regarding not only food products in general, but also organic products in particular (Sudarević, 2000).

Several goals were set regarding the research subject: to look into the choice of the content of the promotional message in relation to other integrated marketing communication activities, to consider this issue in the context of relevant foreign market research into organic product consumers, to study the level of marketing research so far that could be used in approaching the issue from the domestic perspective, and find out which recommendations and implications could be generated regarding domestic organic products.

\section{Methods and materials}

Choosing the content of promotional message as an element of programming integrated marketing communication activities

In view of the fact that the choice of the promotional message content is one of the elements within the process of conducting integrated marketing communication activities, this element first needs to be studied in the context of relation to other activities. More specifically, the activities within the process of conducting integrated marketing communication activities are (Salai, Grubor, 2011):

- identifying the target auditorium of organic products;

- determining the objectives of promoting organic products;

- creating the promotional message of organic products;

- choosing the communication media of organic products;

- defining the total promotional budget of organic products;

- deciding on the promotional mix of organic products;

- measuring the effects of promoting organic products and

- managing and coordinating the marketing communication process of organic products.

Identifying the target auditorium of organic products may refer to current consumers, potential consumer, marketing channels, consumer segments, companies, and specific as well as general public. Identifying the target auditorium is performed based on marketing research information on consumers' demands, needs, wishes, attitudes, motives, habits and preferences. The identified target auditorium is what the decision about marketing communication depends on. 
The ultimate goal of all company's activities is purchase of the product (the economic goal is profit, and communication goal is forming and maintaining of a positive and clear image that will contribute to attaining the economic goal) by providing value, and thus providing long-term consumer loyalty.

Creating the promotional message of organic products refers to four issues, or questions; promotional message content (what to say), promotional message structure (how to say it), promotional message form (how to express it symbolically) and promotional message source (who should say it). The promotional message content is determined by the communicator, given that he assesses what is to be said to the target auditorium in order to provoke the desired response. Appeals can be: rational, emotional and moral. Ideally, the promotional message should attract attention, maintain interest, stimulate desire and lead to action.

The purpose of media, i.e. carriers of integrated marketing communication, is to carry the communicator's unique promotional messages to the target auditorium and can be: personal communication media, i.e. face-to-face communication and impersonal communication media or general communication.

Defining the total promotional budget of organic products in practice involves the application of a whole set of possible methods: the commission method, the remuneration per unit method, the arbitrary method, the competitive parity, the goal and task method, etc. What must particularly be borne in mind is the importance of promotion in the overall marketing mix, which depends on the life cycle stage, frequency of shopping trips, etc.

When deciding on the promotional mix, the promotional budget is allocated to various promotion instruments (mass media advertising, internet advertising, sales promotions, personal sale, media advertising, marketing public relations, direct marketing etc), which company applies depending on the characteristics of individual promotion instruments, type of product market, the stage of the consumers' readiness for shopping and the stage of product life cycle.

Measuring the promotion effect is performed in preliminary research, i.e. pre-testing the promotional message and subsequent studies and measuring, i.e. post-testing (which includes measuring the effect of promotional messages, i.e. memory, perception, and response to the promotional message content).

Management and coordination of marketing communication for organic products are approached from several aspects: the first relies on production life cycle stages and various promotion strategies (from aggressive to reminders) in individual product life cycle on the market as its support. The other approach, the promotion spiral, is based on the concept of the intention to expand the market by extending the product's utilisation range.

Foreign consumer-focussed marketing research for the purpose of choosing the promotional message content for organic products 
Marketing research conducted for the purpose of promoting organic products on foreign markets, primarily EU countries, should mainly be viewed in the context of new tasks set before the promotion by the development of organic product market in these countries (Đokić et al., 2011): to build the image of specialised organic product sales result, to target promotion at occasional organic product consumers, conceive and devise a promotion in the conditions of globalised organic farming product market. Consumer-centred marketing research for the purpose of choosing the promotional message content will be discussed on two studies carried out in EU countries.

The first marketing research was conducted in the UK, in January and February 2003 (Anon, 2004) and dealt with the analysis of respondents' consumption behaviour and attitude formation in 15,000 households using the Super-panel database possessed by Taylor Nelson Sofres, a company conducting marketing research worldwide. These results were expanded with more detailed marketing research into the opinions of respondents in charge of shopping, where further 4,000 people were interviewed in their homes. This marketing research stemmed from the need to increase the understanding of consumer needs, with the aim to promote organic food more effectively and raise sales, and a special accent was placed on the choice of the promotional message content. In addition to general recommendations for marketing and promotion (for more detail, see Đokić et al., 2011) and market segmentation (for more detail, see Đokić, Ćetković, 2013), the above mentioned research enables following the activities of integrated marketing communication.

It starts from segmentation of the organic product market. Three market segments were identified first: heavy, medium and light, in such a manner, that, taking into account the annual consumption of organic product consumers, the first $20 \%$ by consumption volume were categorised as heavy consumers, the following 30\% are medium consumers, whereas the remaining 50\% consumers were characterised as light. Segmentation was continued by introducing a number of organic product categories (fruit and vegetables, eggs, dairy products, packed groceries, fruit juices and soft drinks, pork, poultry, beef and mutton) used by consumers in these market segments. It was concluded that the $23 \%$ heavy consumers accounted for $84 \%$ of the total consumption of organic products that light consumers could only be converted to medium consumers, and medium consumers could be converted to heavy consumers. Medium consumers were therefore defined as the target auditorium. The basic goal is to convert these into heavy consumers, so that organic product market development could continue.

As regards creating the promotional message, special attention was devoted to research consumers' attitudes for the purpose of choosing the promotional message content. This research was conducted on 4,000 respondents in charge of shopping both on the total sample level and on the level of individual market segments (Table 1), and also depending on individual categories of organic products (Table 2). In addition, market segments were defined slightly differently: very light, light, medium and heavy consumers (Table 1). 
Table 1. Promotional message content and market segments (shaded background statistically significant difference at 95\% level).

\begin{tabular}{|c|c|c|c|c|c|}
\hline & 흘 & 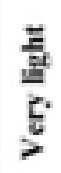 & $\frac{\vec{E}}{\underline{y}}$ & $\frac{\mathrm{E}}{\frac{\mathrm{E}}{\mathrm{z}}}$ & 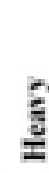 \\
\hline Organic tastes better & 24 & 20 & 27 & 23 & 23 \\
\hline Food safety concems & 22 & 14 & 22 & 29 & 27 \\
\hline Wish to reduce exposure to pesticides & 18 & 9 & 16 & 26 & 22 \\
\hline GM food concerns & 15 & 9 & 16 & 18 & 16 \\
\hline Environmental concerns & 15 & 7 & 12 & 26 & 15 \\
\hline Products from organic farms are higher quality & 15 & 7 & 16 & 22 & 16 \\
\hline Animal welfare concerns & 14 & 10 & 12 & 21 & 16 \\
\hline Organic products contain more minerals and vitamins & 10 & 5 & 12 & 14 & 10 \\
\hline High awareness of organic approach & 9 & 3 & 8 & 18 & 11 \\
\hline For my children & 8 & 4 & 7 & 10 & 9 \\
\hline Modical advice & 6 & 4 & 5 & 9 & 7 \\
\hline I know a local organic producer & 5 & 4 & 5 & 6 & 8 \\
\hline None of the above & 11 & 21 & 10 & 2 & 9 \\
\hline Don't know & 10 & 18 & 7 & 5 & 9 \\
\hline
\end{tabular}

Source: Annon (2004).

Table 2. Promotional message contents and organic product categories (shaded background - statistically significant difference at 95\% level).

\begin{tabular}{|c|c|c|c|c|c|c|c|c|}
\hline & 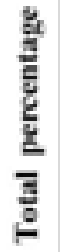 & 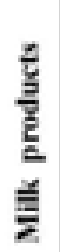 & de & $\mathrm{g}$ & 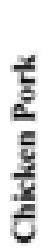 & $\frac{\text { g }}{\frac{\mathrm{g}}{\mathrm{g}}}$ & $\frac{E}{\frac{E}{2}}$ & 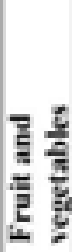 \\
\hline Organic tastes better & 24 & 23 & 27 & 23 & 31 & 23 & 17 & 25 \\
\hline Food safety concems & 22 & 23 & 24 & 18 & 12 & 23 & 25 & 23 \\
\hline Wish to reduce exposure to pesticides & 18 & 16 & 12 & 24 & 20 & 26 & 14 & 20 \\
\hline GM food concerns & 15 & 12 & 14 & 23 & 24 & 17 & 20 & 16 \\
\hline Environmental concerns & 15 & 13 & 13 & 12 & 18 & 19 & 20 & 15 \\
\hline Products from organic farms are higher quality & 15 & 17 & 12 & 6 & 16 & 20 & 31 & 14 \\
\hline Animal welfare concerns & 14 & 11 & 22 & 12 & 15 & 15 & 11 & 13 \\
\hline Organic products contain more minerals and vitamins & 10 & 12 & 8 & 21 & 5 & 20 & 16 & 11 \\
\hline High awareness of organic approach & 9 & 8 & 9 & 6 & 5 & 18 & 3 & 10 \\
\hline For my children & 8 & 7 & 5 & 2 & 5 & 10 & 22 & 8 \\
\hline Medical advice & 6 & 11 & 5 & 10 & 1 & 19 & 3 & 4 \\
\hline I know a local organic producer & 5 & 3 & 6 & 5 & 9 & 2 & 6 & 5 \\
\hline None of the above & 11 & 11 & 6 & 15 & 7 & 12 & 8 & 11 \\
\hline Don't knows & 10 & 6 & 9 & 12 & 8 & 4 & 4 & 10 \\
\hline
\end{tabular}

Source: Annon (2004). 
Buying organic food usually begins by buying organically grown food and vegetables, followed by eggs and dairy products, then packed food in grocery shops, and finally, meat and soft drinks.

Bearing in mind the conclusion that two basic motives driving organic product consumers are taste and health, and also that these are the essential factors in stimulating consumers to try organic products for the first time, recommendations are given about promoting organic products to medium consumers.

The other example is the Farmer Consumers Partnership project (2007-2010), which encompassed conducting several marketing research projects in Austria, Germany, Italy, Switzerland and the United Kingdom, with the aim to choose the promotional message content to be used in communication with organic product consumers. This project emerges in a setting where organic producers in Europe increasingly fear competition originating from producers from the countries where production costs are significantly lower due to climatic conditions, lower labour or land cost, or lower production standards. On the other hand, the consumers are dissatisfied because of the consequences of organic food market, with the high presence of anonymous, uniform and replaceable organic products produced under unfavourable social or environmental conditions. The project assumption and results were published in four works: Padel \& Gössinger (eds.), 2008; Zander \& Hamm (eds.), 2009; Naspetti \& Zanoli (eds.), 2010; and Stolz \& Stolze (eds.), 2010.

In the first part of the project (Padel \& Gössinger (eds.), 2008), based on literature review and the positions of suppliers and their initiatives, promotional message contents were defined that were expected to be most effective. The initial point was research into the concept of ethical consumerism and corporate social responsibility and identifying the "organic plus" value. 72 different promotional message contents were identified as used by companies supplying organic products in the above listed 5 countries. This number was reduced to 14 through expert assessment, with 2 different promotional message contents for each of the following ethnical attributes: biodiversity, animal welfare, regional production, fair trade, farm welfare, social aspect of production and preservation of cultural characteristics.

The second part of the project (Zander \& Hamm (eds.), 2009) included offering two different promotional message contents within defined ethical attributes to consumers in the five observed countries, and then adding price, with the aim to test the influence of these different promotional message contents on the choice of products with desired characteristics. Marketing research was based on the application of the information-display-matrix technique.

A two-dimensional matrix displays the alternative product varieties in columns, whereas rows present their attributes, where the intersection fields contain various hidden promotional message contents, describing the content of product-related attributes, which must be approached successively so as to reach the information. This is a possible way of identifying relevant criteria relating to the product and their relative importance for the purchase decision.

In this specific case, the two-dimensional matrix lists the types of organic milk in columns, while ethical attributes are given to surveyed consumers accessing this matrix to make a 
choice, while the fields whose content is not immediately seen are at the intersections of columns and lines.

When the consumer accesses the matrix, the promotional message about an ethical attribute of organic milk, invisible until then, appears (Figure 1). One by one field must be accessed to get information. After closing the field whose content was disclosed to the consumer, its colour would change so that the consumers could know which fields they had opened. Also, they could highlight particularly interesting fields with a third colour, and the same fields could be opened several times. When the consumer would decide to "buy" a certain product (s)he had to click the header of the chosen product (i.e. the top of the column where its name is stated). The software would then ask the consumer to confirm the decision (Figure 2) and store the information on the order of accessing individual field, time devoted to each individual field, and the total time until making the purchase decision.

The results indicate that the most popular ethical attribute for promoting "organic plus" value are animal welfare, regional or local food production and fair trade.

Figure 1. The information-display-matrix with open promotional message content with "animal welfare" ethical attribute of organic milk B

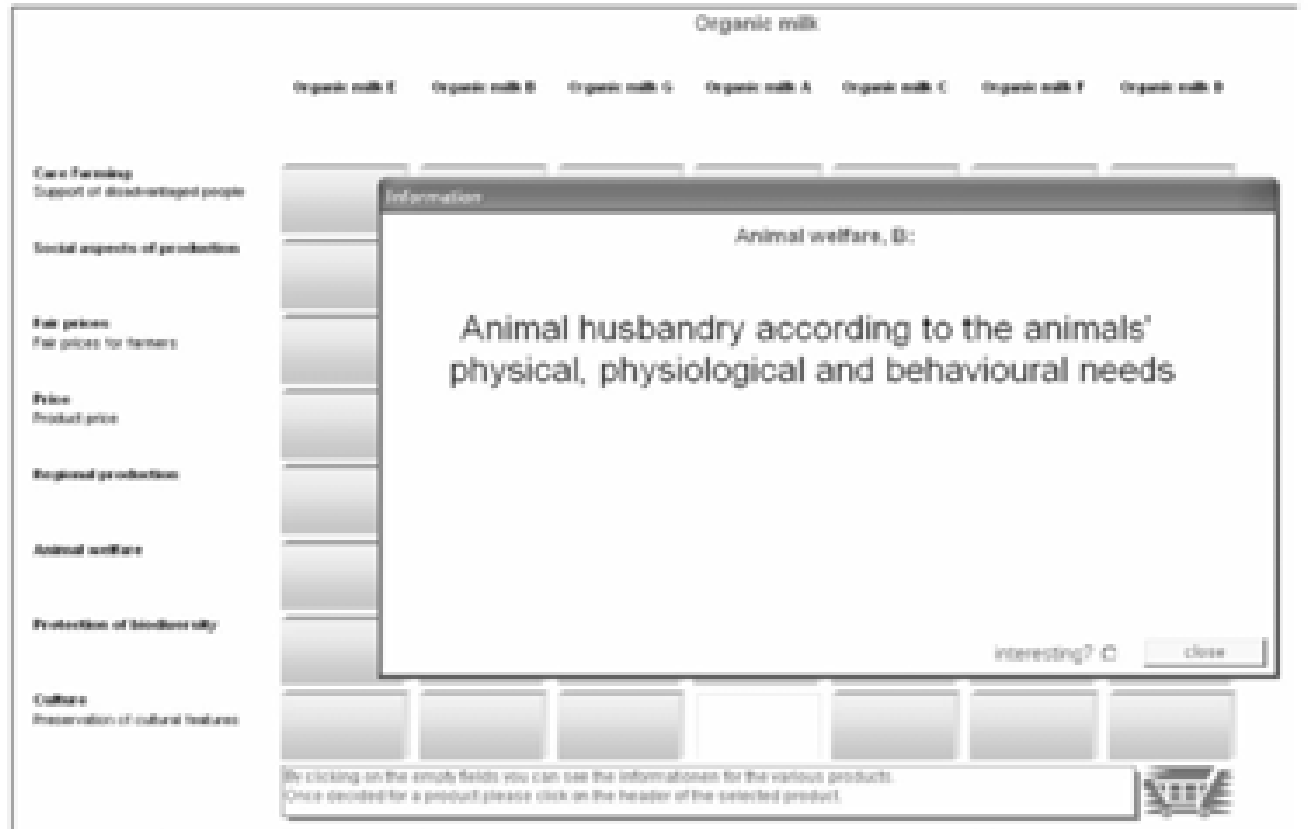

Saurce: Zander, K.\& Hawm, U. (eds) (2009). Fanwer Consener Parperships - Informatiow search and decision making - the case of ethical values of organic products. Tjele: Intemational Centre for Research in Onganic Food Sysiems (ICROFY). 
Figure 2. The information-display-matrix - choice of organic milk C

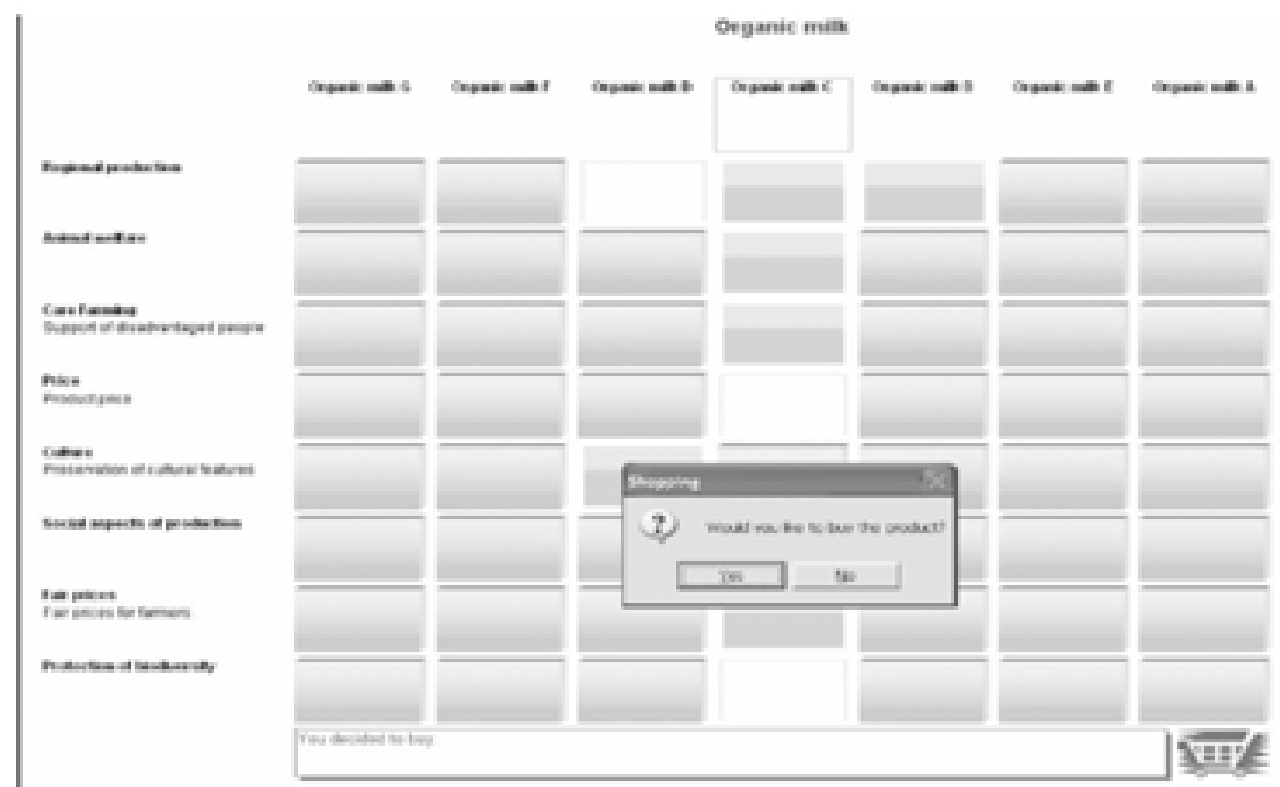

Sawre: Zanker, K.\& Hawm, U. (eds.) (2000). Farmer Consemer Partnerships - Lnformation search and decision making - the case of ethical values of organic products. Tjele: International Centre for Research in Onganic Food Siskems (KCROFS).

In the third part of the project (Naspetti, Zanoli (eds.), 2010) labels with two arguments each were made for all three chosen attributes (animal welfare, regional or local food production and fair trade), and consumers'impressions about made labels were researched, in this case, on the example of organic eggs. Discussion on the made labels was conducted in eighteen focus groups in all five countries. The opinions on labels were expressed through discussion, and then through a questionnaire. In the second stage, a recollection study of offered arguments was performed, ten days after the discussion in focus groups. Results were related to the appeal, persuasiveness, reliability and effectiveness of the label. The consumers did not express sympathy to arguments related to their own emotions. Animal welfare was the most preferred argument, local food production took up the second place, while the third place was taken up by fair trade. As for argument persuasiveness, difference between individual was more manifest, while effectiveness was measured through purchase intention.

The fourth part of the project (Stolz, Stolze (eds.), 2010) consisted of market research conducted in all five countries, by means of consumer choice experiments. The research subject was consumers' preferences and willing to pay for organically produced eggs, with the following contents printed or not printed on the packaging: country of origin (e.g. Great Britain), region of origin (e.g.) Berkshire), with the highest animal welfare standards, and fair price for organic farmers, plus twenty cents extra. Each consumer evaluated maximum one of three offered packages in six sets (it was possible to choose none). Each set included two packages featuring one or several contents printed, 
whereas one package did not feature any content, and was the lowest-priced. After this, a questionnaire was filled in, so as to research the variables of market segmentation that could describe consumers with different preferences.

The consumers showed higher preference for eggs whose packaging featured the above mentioned contents than those featuring no content, but the preference varied depending on the content and the country. Stating the regional origin was preferred most in all countries except Austria, where the fact that eggs were produced with the highest animal welfare standards and originated from a certain country accounted for more preference. On the other hand, stating that the organic eggs were produced with the highest animal welfare standards was less preferred in Germany and Switzerland than stating the region. The Germans and the Swiss also preferred the statement that the eggs were fair trade products (and 20 cents more expensive), but only after stating a certain region and the fact that the eggs were produced with the highest animal welfare standards.

Final outcome of the research gave the following picture: the higher the consumers' education level, the higher the share of organic food and drinks in their shopping, the more preference of a certain region; the higher the consumers' purchasing power, the higher share of organic food and drinks in their shopping cart, involvement in animal welfare, belief that the government and food producers should apply high animal welfare standard levels and the farmers should be subsidised for integrating these standards in the production system, the more preferred statement that organic eggs were produced with the highest animal welfare standards.

Although partially the message content differs from the one shown in the previous section, and although the message content is presented only by means of packaging of the organic product, the second project presented in this section of the paper confirms the importance of conducting consumer-centred marketing research for the purpose of choosing the promotional message content. The above mentioned differences, notably in terms of choosing the target audience in the second stage do not diminish the image of the importance of the topic of this article in foreign research. In relation to this, at the same time, relatively less space was devoted to presenting the information-display-matrix as an underrated technique in domestic marketing research that can be implemented for promotional purposes.

\section{Results and discussion}

Consumer-centred marketing research for the purpose of choosing the promotional message content for domestic organic products

Whether we opt for export or turn to domestic consumers, the placement of domestic organic products should be based on the marketing concept principles. As regards promoting these products, what is needed is managing all the integrated marketing communication activities, including the choice of the promotional message content, which requires consumer-centred marketing research for its purposes. 
Before choosing the promotional message content, it is necessary to define the target auditorium, i.e. segment the market. Notably, the already defined segments can be studied further, e.g. in Serbia: mothers with infants, the health conscious, the elderly, the young and fashion conscious (Stevanović, 2010), or the research can be conducted on a representative sample of the general population. One of the possible approaches is food-related lifestyle market segmentation. Food-related lifestyle is, in fact, the basic pattern of how consumers use food to fulfil the basic drives and achieve core life values (Brunsø et al., 2002).

Another possible approach to market segmentation is preference-based market segmentation. The advantages of organic consumers' preference-based market segmentation could principally be identified in possibilities of (Đokić et al., 2012):

- wording the question in a manner that suits the choice in real-life shopping situations consumers find themselves in;

- reducing the amount of socially desirable bias;

- testing the significance of various other (socio-demographic, psychographic and/or behavioural) market segmentation criteria for describing identified segments;

- increasing the comparability of results of different pieces of research;

- using them in planned new product launches and on emerging and developing markets;

- studying the difference between expressed preferences and purchases, in terms of obstacles to translating preferences into purchases.

As regards the objectives of promoting organic products, it is beyond doubt that the ultimate goal is the sale of the placed domestic products. Moreover, if the placement occurs on organic food markets in the initial development stages, a special attention must be devoted to educating the general population on value added characteristic of the products, on institutional market development and on distribution channel development. It is the value added that communicates with consumers by using various, targeted appeals that should be in compliance with the consumers' motives and desires (Davčik, 2004).

The choice of organic products' promotional message is also possible based on previous research, but the ideal option is to conduct consumer-centred marketing research for the purpose of choosing this content. To this purpose, it is possible to use the focus group or in-depth interviews, starting from the means-end approach to consumer behaviour based on the assumption that consumers are not interested in the product per se, but in what the product enables them to achieve (Grunert, 2005). Laddering is the most used technique in this respect in order to study how consumers create mental associations from product characteristics to a more abstract quality dimensions, down to core life values. The results of these studies are mostly presented in hierarchical value maps. Organic products are characterised by credence quality, which will be based on earlier inference even after the purchase.

As regards the domestic organic product market, some studies can be cited that also refer to promotional message contents. It is emphasised (Stefanović, 2010) that an 
average consumer in Serbia associated words "organic" and "healthy", and future market development requires intensive campaign with a clear communication strategy targeting defined consumer segments: mothers with infants, the health conscious, the elderly, the young and fashion conscious, where the promotion activities and health food awarenessraising campaign would focus on health and highlight the natural features of such food and its significance for environmental protection. Results of conducted research (Vlahović et al., 2010) point out that younger generations are more motivated for consuming organic food, both for environmental and health concerns. Other conducted research (Đokić, Tomić, 2011) argues that the promotional message content could also refer to the dynamic concept of quality immanent to organic products.

The authors' proposal regarding the choice of promotional message content for domestic organic products would include themes "the way our grandparents did", or "ethno-style" for domestic consumers. As for placement to developed foreign markets, provided that the diasporas is not the target auditorium, the country's image needs to be working on in general, simultaneously with providing a sufficient quantity of supply. In addition to research on the example of specific products, it is also necessary to research the content of promotional message to various segments.

When choosing the promotional content, certain legal limitations must be borne in mind as well e.i. limitations stemming from the EU legislation regarding the health related claims that would be used in product promotion (Aschemann et al., 2008). Health claim is defined as "any claim stating, suggesting or implying that there is a relationship between food category or one of its ingredients and health". Thus, the Regulation on Nutrition and Health Claims Made on Foods (EC No 1924/2006) was passed in order to harmonise similar regulations within the EU and customer protection, and pertains to all claims on nutrition and its health impacts stated on packaging, in advertising, even in brands.

\section{Conclusion}

Promoting organic food products requires conducting integrated marketing communication activities. Choosing the promotional message content, together with designing the structure, form and source of promotional message, is a part of creating a promotional message within the integrated marketing communication activities. The research subject in this article was consumer-centred marketing research for the purpose of choosing the promotional message content for foreign and domestic organic products that resulted in several practical recommendations:

- maintain detailed communication with all consumer segments about food quality (include avoiding the use of pesticides and additives, and especially highlight the nutritional value);

- "tell the organic story" so that the promotional message content includes the origin of the product;

- $\quad$ use the appeal to buy domestic products produced "the way our grandparents did", in "ethno-style"; 
- include various benefits of consuming organic product (possible through information provided on the product packaging, encouraging visits to farms, developing contacts with the media);

- highlight the taste of products in the promotional message content, and, in relation to this, organise promotional tasting events;

- create promotional messages of simple content, which would suggest consumers how to identify organic products and distinguish them from other "natural" ones;

- emphasise the health benefits in the promotional message content, to the extent allowed by advertising legislation;

- develop relations and connections with humanitarian environmental organisations.

\section{Acknowledgment}

The authors gratefully acknowledge financial support from the Ministry of Education and Science of the Republic of Serbia (Project III 46005).

\section{References}

1. Annon, A. (2004): Organic Food: Understanding the Consumer and Increasing Sales, Aberystwyth: Organic Centre Wales.

2. Aschemann, J., Maroscheck, N., Hamm, U. (2008): The EU health claims regulation and its impact on the marketing of organic food, Paper presented at the $2^{\text {nd }}$ scientific conference of the International Society of Organic Agriculture Research (ISOFAR), Modena, Italy.

3. Brunsø, K., Fjord, T. A., Grunert, K. G. (2002): Consumers' food choice and quality perception (MAPP Working Paper 77), Aarhus: The Aarhus School of Business.

4. Davčik, N. S. (2004): Marketing strategija proizvoda u industriji hrane: ekološki pristup, Ecologica, vol. 11(43), pp. 1-8.

5. Đokić, N., Ćetković, B. (2013): Značaj segmentacije tržišta organskih poljoprivrednih proizvoda za održivi razvoj, Paper presented at the $18^{\text {th }}$ scientific conference Strategic Management and Decision Support Systems in Strategic Management (SM2013), Palić, Serbia.

6. Đokić, N., Kočić Vugdelija, V., Berber, N. (2011): Uticaj razvoja tržišta na promociju organskih poljoprivrednih proizvoda, Ekonomika poljoprivrede, vol. 58(3), pp. 425-441.

7. Đokić, N., Tomić, G. (2011): Dinamički koncept kvaliteta u funkciji razvoja tržišta organskih poljoprivrednih proizvoda, Paper presented at the $16^{\text {th }}$ scientific conference Strategic Management and Decision Support Systems in Strategic Management (SM2011), Palić, Serbia.

8. Djokic, N., Salai, S., Mesaros, I. (2012): Approaches to organic produce market segmentation, Paper presented at the $1^{\text {st }}$ WSEAS International Conference on Economics, Political And Law Science (EPLS ‘12), Zlin, The Czech Republic.

9. Grunert, K. G. (2005): Food quality and safety: Consumer perception and demand, 
European Review of Agricultural Economics, vol. 32(3), pp. 369-391.

10. Grunert, K. G., Larsen, H. H., Madsen, T. K., Baadsgaard, A. (1996): Market Orientation in Food and Agriculture, Norwell, MA: Kluwer.

11. Hughner, R. S., McDonagh, P., Prothero, A., Shultz, C. J., Stanton, J. (2007): Who are organic food consumers? A compilation and review of why people purchase organic food, Journal of Consumer Behaviour, vol. 6(2,3), pp. 94-110.

12. Jobber, D., Fahy, J. (2006): Osnovi marketinga, Belgrade: Data status.

13. Kotler, P., Keller, K. L. (2006): Marketing menadžment, Belgrade: Data status.

14. März, U., Stolz, T., Kalentić, M., Stefanović, E. (2012): Organic agriculture in Serbia 2012-At a Glance, Belgrade: Serbia Organica National Association.

15. Mesaroš, I., Đokić, N., Penić, M. (2013): Measuring the communication effects of sales promotion in a food company, Ekonomika poljoprivrede, IEP Beograd, vol. 60, no. 1, IEP, Srbija.

16. Naspetti, S., Zanoli, R. (eds.), (2010): Farmer Consumer Partnerships - Elaboration and test of new communication concepts, Tjele: International Centre for Research in Organic Food Systems (ICROFS).

17. Padel, S., Gössinger, K. (eds.), (2008): Farmer Consumer Partnerships - Communicating Ethical Values: a conceptual framework, Tjele: International Centre for Research in Organic Food Systems (ICROFS).

18. Salai, S. (2004): Integralno marketing komuniciranje (sa posebnim osvrtom na proizvode organske poljoprivrede), Anali Ekonomskog fakulteta u Subotici, vol. 11, pp. 63-73.

19. Salai, S. (2005): Promocija marke proizvoda organske poljoprivrede, Anali Ekonomskog fakulteta u Subotici, vol. 13, pp. 67-75.

20. Salai, S., Grubor, A. (2011): Marketing komuniciranje, Subotica: Ekonomski fakultet Subotica.

21. Stefanović, E. (2010): Rezultati studije istraživanja tržišta organske hrane Srbije, Report presented at the Conference on organic agriculture "Selenča 2010", Selenča, Serbia.

22. Stolz, H., Stolze, M. (eds.), (2010): Farmer Consumer Partnerships - Report on the results of Consumer Choice Experiments, Tjele: International Centre for Research in Organic Food Systems (ICROFS).

23. Sudarević, T. (2000): Alternativni koncept promotivnih aktivnosti prehrambenih proizvoda, Anali Ekonomskog fakulteta u Subotici, vol. 5, pp. 333-339.

24. Sudarević, T., Salai, S., Pupovac, Lj. (2011): Marketing aspekti ponude organskih poljoprivrednih proizvoda u Srbiji i okruženju, Anali Ekonomskog fakulteta u Subotici, vol. 47(26), pp. 33-48.

25. Vlahović, B., Tomić, D., Popović, V. (2010): Stanje i perspektive potrošnje proizvoda organske poljoprivrede, Paper presented at the Conference on organic agriculture "Selenča 2010", Selenča, Serbia. 
26.Zander, K., Hamm, U. (eds.), (2009): Farmer Consumer Partnerships - Information search and decision making - the case of ethical values of organic products, Tjele: International Centre for Research in Organic Food Systems (ICROFS).

\title{
MARKETING ISTRAŽIVANJE U FUNKCIJI IZBORA SADRŽAJA PROMOTIVNE PORUKE DOMAĆIH ORGANSKIH PROIZVODA
}

\author{
Suzana Salai ${ }^{5}$, Tomislav Sudarević, ${ }^{6}$ Nenad Đokić ${ }^{7}$, Ljubomir Pupovac $^{8}$
}

\begin{abstract}
Rezime
Izbor sadržaja promotivne poruke spada u aktivnosti integrisanih marketing komunikacija. Kada su u pitanju organski proizvodi u svetu, istraživanjima u vezi sa izborom sadržaja promotivne poruke posvećuje se velika pažnja prvenstveno na osnovu realizacije marketing istraživanja potrošača tih proizvoda. Promocija domaćih organskih proizvoda takođe nužno podrazumeva realizaciju marketing istraživanja potrošača u funkciji izbora sadržaja promotivne poruke. S tim u vezi, u ovom radu je definisano nekoliko ciljeva: istražiti izbor sadržaja promotivne poruke u odnosu na ostale aktivnosti integrisanih marketing komunikacija, istražiti navedeno pitanje u kontekstu relevantnih inostranih marketing istraživanja potrošača organskih proizvoda, sagledati nivo dosadašnjih marketing istraživanja koja bi iz domaće perspektive mogla koristiti pristupanju navedenoj problematici, kao i istražiti koje preporuke i implikacije bi se mogle generisati kada su u pitanju domaći organski proizvodi.
\end{abstract}

Ključne reči: organski proizvodi, marketing istraživanje potrošača, integrisane marketing komunikacije, aktivnosti integrisanih marketing komunikacija, izbor sadržaja promotivne poruke.

5 Prof. dr, redovni profesor u penziji, Ekonomski fakultet Subotica, Univerzitet Novi Sad, Segedinski put 9-11, 24000 Subotica, Srbija, E-mail: sazu@ef.uns.ac.rs

6 Prof. dr, vanredni profesor, Ekonomski fakultet Subotica, Univerzitet Novi Sad, Segedinski put 9-11, 24000 Subotica, Srbija, E-mail: tsudarevic@yahoo.com

7 M.A., asistent, Ekonomski fakultet Subotica, Univerzitet Novi Sad, Segedinski put 9-11, 24000 Subotica, Srbija, E-mail: djokicn@ef.uns.ac.rs

8 M.Sc., asistent, Ekonomski fakultet Subotica, Univerzitet Novi Sad, Segedinski put 9-11, 24000 Subotica, Srbija, E-mail:1jubomirp@ef.uns.ac.rs

EP 2014 (61) 2 (501-515) 